\title{
Pox proteomics: mass spectrometry analysis and identification of Vaccinia virion proteins Jennifer D Yoder ${ }^{1}$, Tsefang S Chen ${ }^{1}$, Cliff R Gagnier ${ }^{1}$, Srilakshmi Vemulapalli ${ }^{2}$, Claudia S Maier ${ }^{3}$ and Dennis E Hruby*1
}

Address: ${ }^{1}$ Oregon State University, Department of Microbiology, 220 Nash Hall, Corvallis, OR 97331-3804, USA, ${ }^{2}$ Oregon State University, Applied Biotechnology Program, 2082 Cordley Hall, Corvallis, OR 97331-8530, USA and ${ }^{3}$ Oregon State University, Department of Chemistry, 153 Gilbert Hall, Corvallis, OR 97331-4003, USA

Email: Jennifer D Yoder - yoderj@science.oregonstate.edu; Tsefang S Chen - susan.yeh@cox.net; Cliff R Gagnier - gagnierc@onid.orst.edu; Srilakshmi Vemulapalli - vemulasr@onid.orst.edu; Claudia S Maier - claudia.maier@oregonstate.edu;

Dennis E Hruby* - hrubyd@oregonstate.edu

* Corresponding author

Published: 0 I March 2006

Virology Journal 2006, 3:10 doi:10.1186/1743-422X-3-10

This article is available from: http://www.virologyj.com/content/3/I/I0

(C) 2006 Yoder et al; licensee BioMed Central Ltd.

This is an Open Access article distributed under the terms of the Creative Commons Attribution License (http://creativecommons.org/licenses/by/2.0), which permits unrestricted use, distribution, and reproduction in any medium, provided the original work is properly cited.
Received: 16 February 2006

Accepted: 01 March 2006

\begin{abstract}
Background: Although many vaccinia virus proteins have been identified and studied in detail, only a few studies have attempted a comprehensive survey of the protein composition of the vaccinia virion. These projects have identified the major proteins of the vaccinia virion, but little has been accomplished to identify the unknown or less abundant proteins. Obtaining a detailed knowledge of the viral proteome of vaccinia virus will be important for advancing our understanding of orthopoxvirus biology, and should facilitate the development of effective antiviral drugs and formulation of vaccines.
\end{abstract}

Results: In order to accomplish this task, purified vaccinia virions were fractionated into a soluble protein enriched fraction (membrane proteins and lateral bodies) and an insoluble protein enriched fraction (virion cores). Each of these fractions was subjected to further fractionation by either sodium dodecyl sulfate-polyacrylamide gel electophoresis, or by reverse phase high performance liquid chromatography. The soluble and insoluble fractions were also analyzed directly with no further separation. The samples were prepared for mass spectrometry analysis by digestion with trypsin. Tryptic digests were analyzed by using either a matrix assisted laser desorption ionization time of flight tandem mass spectrometer, a quadrupole ion trap mass spectrometer, or a quadrupole-time of flight mass spectrometer (the latter two instruments were equipped with electrospray ionization sources). Proteins were identified by searching uninterpreted tandem mass spectra against a vaccinia virus protein database created by our lab and a non-redundant protein database.

Conclusion: Sixty three vaccinia proteins were identified in the virion particle. The total number of peptides found for each protein ranged from I to 62, and the sequence coverage of the proteins ranged from $8.2 \%$ to $94.9 \%$. Interestingly, two vaccinia open reading frames were confirmed as being expressed as novel proteins: E6R and L3L. 


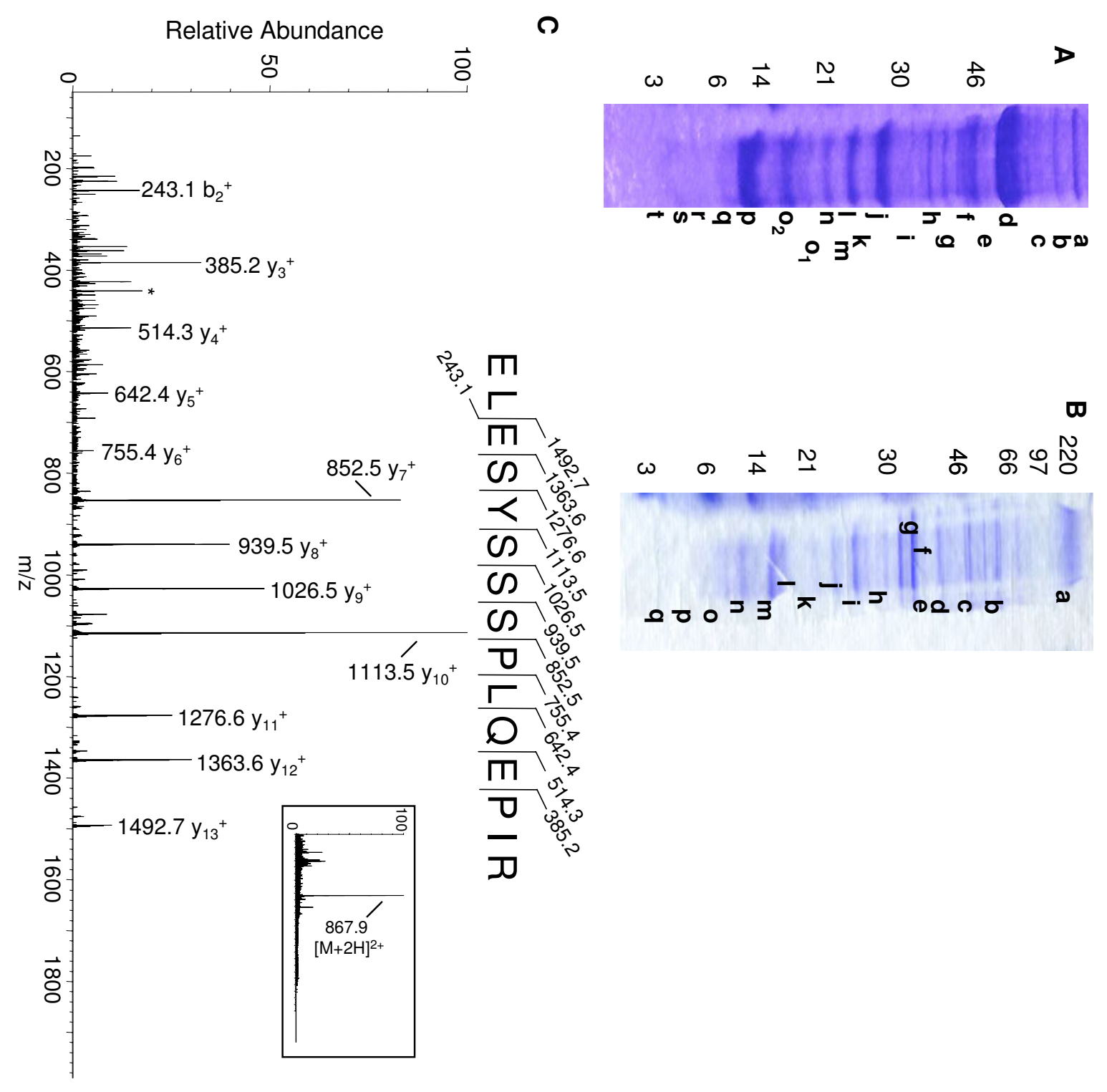

Figure I

Mass analysis of a distinct peptide from the L4R protein using Method I (SDS-PAGE + LC-ESI-Q-TOF MS)

Panel A shows the Coomassie blue stained SDS-PAGE gel of the core-enriched fraction and panel B is the membrane-enriched fraction. Gel slices that were analyzed by MS are denoted with letters. The full scan mass spectrum (inset of $C$ ) displays a doubly charged parent ion at $\mathrm{m} / \mathrm{z}$ 867.9. The corresponding tandem mass spectrum (C) identifies a peptide of the L4R protein.

Asterisks (*) denote the loss of ammonia $\left(\mathrm{NH}_{3}\right)$ or water $\left(\mathrm{H}_{2} \mathrm{O}\right)$.

\section{Background}

Variola virus (smallpox agent) and/or genetically-engineered orthopoxviruses are considered one of the most significant Category A pathogenic threats for malevolent use as potential agents of bioterrorism [1]. Due to the bioterrorism threat, there is a renewed public interest in the development of effective anti-poxvirus $\operatorname{drug}(\mathrm{s})$ and/or vaccines for use in treating or preventing human diseases caused by pathogenic poxviruses. Because the nucleotide sequence of the variola virus is approximately $90 \%$ identical with that of the vaccinia virus, VV [2], we hypothesize that VV can act as a model for variola. At present, there are no effective anti-orthopoxvirus drugs available, and the Dryvax vaccine used during the eradication campaign is not considered safe for general use, considering immuno- 
Table I: Vaccinia virion proteins identified in this study. Membrane- and core-enriched fractions were both analyzed by five different methods: Method I (SDS-PAGE + LC-ESI-Q-TOF MS), Method 2 (SDS-PAGE + LC-ESI-QIT MS), Method 3 (HPLC + LC-ESI-QIT MS), Method 4 (LC-ESI-Q-TOF MS), and Method 5 (MALDI-TOF/TOF MS). Identified proteins are listed according to their corresponding ORF. The total number of non-redundant peptides and the percent of the protein identified are recorded.

\begin{tabular}{|c|c|c|c|c|c|}
\hline ORF & Function/location & Ref. & Methods & \# peptides & $\%$ Coverage \\
\hline $\mathrm{A} 3 \mathrm{~L}$ & Major core protein & [17] & $1,2,3,4,5$ & 39 & 71.6 \\
\hline $\mathrm{A} 4 \mathrm{~L}$ & IMV/P4a associated protein & [18] & $1,2,3,4,5$ & 16 & 49.1 \\
\hline A5R & RNA pol. subunit & [19] & $1,4,5$ & 3 & 29.9 \\
\hline A7L & Early transcription factor & [20] & $1,2,4,5$ & 7 & 12.7 \\
\hline AIOL & Major core protein & [2I] & $1,2,3,4,5$ & 62 & 64.3 \\
\hline $\mathrm{A} / 2 \mathrm{~L}$ & Viral structural protein & [22] & $1,3,4$ & 4 & 14.6 \\
\hline AI3L & Membrane phosphoprotein & [23] & $1,2,3,4,5$ & 6 & 91.4 \\
\hline Al4L & Membrane phosphoprotein & [23] & $1,2,4,5$ & 4 & 61.1 \\
\hline AI5L & Core assoc. protein & [24] & $1,2,3$ & 5 & 60.2 \\
\hline Al6L & Myristoylprotein; entry/fusion & {$[25,26]$} & $1,2,5$ & 4 & 12.2 \\
\hline AI7L & IMV membrane prtn & {$[27,28]$} & $1,2,4,5$ & 4 & 32.0 \\
\hline A24R & RNA pol. subunit & [29] & $1,2,4,5$ & 26 & 30.9 \\
\hline A27L & IMV membrane prtn & [30] & $1,2,3,4,5$ & 17 & 70.0 \\
\hline A29L & RNA pol. subunit & [3I] & 2,5 & 2 & 8.2 \\
\hline $\mathrm{A} 30 \mathrm{~L}$ & Virion component & [32] & $2,3,4,5$ & 3 & 58.4 \\
\hline A33R & EEV glycoprotein & [33] & I,4,5 & 2 & 21.6 \\
\hline A34R & EEV glycoprotein & [34] & $1,2,4$ & 2 & 23.2 \\
\hline$A 42 R$ & Profilin homolog & [35] & $1,2,3,4,5$ & 6 & 51.1 \\
\hline A46R & Interact with host IL-I & [36] & 1 & 2 & 12.6 \\
\hline A56R & EEV glycoprtn, hemagglutinin & [37] & $1,4,5$ & 3 & 12.4 \\
\hline B5R & EEV glycoprotein & [38] & 4 & 2 & 10.4 \\
\hline$B 22 R$ & Serpin (CI6L) & [39] & $1,2,4,5$ & 3 & 19.9 \\
\hline DIR & Capping enzyme subunit & [40] & $1,2,4,5$ & 15 & 22.7 \\
\hline $\mathrm{D} 2 \mathrm{~L}$ & virion component & [4I] & $1,2,4,5$ & 9 & 63.0 \\
\hline D3R & virion component & [4I] & $1,2,4,5$ & 8 & 50.6 \\
\hline D6R & Early transcription factor & [42] & 2,5 & 7 & 11.9 \\
\hline D8L & IMV membrane protein & {$[43,44]$} & $1,2,3,4,5$ & 26 & 89.1 \\
\hline DIIL & DNA-dependent ATPase & [45] & $1,2,5$ & 9 & 17.3 \\
\hline DI2L & Capping enzyme subunit & [46] & $1,2,4,5$ & 8 & 40.4 \\
\hline EIL & PolyA polymerase & {$[47,48]$} & $2,4,5$ & 4 & 11.1 \\
\hline E3L & dsRNA dep. protein kinase & [49] & 1,5 & 1 & 13.2 \\
\hline E4L & RNA polymerase & [50] & $1,2,4,5$ & 5 & 27.8 \\
\hline$E 6 R$ & unknown & & $1,2,4,5$ & 20 & 43.1 \\
\hline E8R & Virion component & {$[51,52]$} & $1,2,4,5$ & 11 & 57.1 \\
\hline EIOR & Oxidase & [53] & $2,3,4,5$ & 2 & 17.9 \\
\hline EIIL & Viral core protein & [54] & $1,2,4,5$ & 2 & 26.4 \\
\hline $\mathrm{F} 8 \mathrm{~L}$ & Cytosolic protein & [55] & $3,4,5$ & 4 & 60.0 \\
\hline F9L & Mem. prtn.; similarity to LIR & [53] & $1,2,3,5$ & 4 & 22.6 \\
\hline $\mathrm{FIOL}$ & Protein kinase & {$[56,57]$} & $1,2,5$ & 4 & 15.7 \\
\hline $\mathrm{FI} \mathrm{LL}$ & EEV membrane protein & [58] & I,2,4,5 & 9 & 32.0 \\
\hline FI7R & DNA binding phosphoprotein & [59] & $1,2,3,4,5$ & 9 & 55.4 \\
\hline GIL & metalloproteinase & {$[60]$} & $1,2,4,5$ & 10 & 19.1 \\
\hline G3L & Entry/fusion complex & [6I] & $2,3,4,5$ & 6 & 41.4 \\
\hline G4L & glutaredoxin & [62] & $2,3,4,5$ & 11 & 77.4 \\
\hline G7L & Core cmpnnt, partners w/A30L & [63] & $1,2,3,4,5$ & 20 & 59.8 \\
\hline HIL & Protein phosphatase & [64] & $1,2,3,4,5$ & 10 & 67.3 \\
\hline $\mathrm{H} 3 \mathrm{~L}$ & Immunodominant protein & [65] & I,2,3,4,5 & 31 & 79.0 \\
\hline $\mathrm{H} 4 \mathrm{~L}$ & RNA pol. associated protein & [66] & $1,2,4,5$ & 5 & 10.6 \\
\hline H5R & Membrane phosphoprotein & [67] & $1,2,3,4,5$ & 8 & 49.3 \\
\hline IIL & encapsidated DNA-binding prtn & [68] & $1,2,3,4,5$ & 6 & 20.5 \\
\hline 13L & DNA binding phosphoprotein & {$[69,70]$} & 2,5 & 3 & 18.6 \\
\hline $15 \mathrm{~L}$ & Virion component & [7I] & 1,4 & 5 & 94.9 \\
\hline 17L & Core protein proteinase & [72] & 2 & 9 & 18.4 \\
\hline I8R & RNA/DNA-dependant NTPase & [73] & 4,5 & 4 & 8.7 \\
\hline JIR & IMV membrane protein & [74] & $1,2,4,5$ & 5 & 30.1 \\
\hline$J 3 R$ & Poly(A) polymerase, RNA methyltransferase & {$[48,75]$} & $1,2,4,5$ & 14 & 47.4 \\
\hline J4R & RNA polymerase & [76] & $1,2,4$ & 6 & 38.4 \\
\hline J6R & RNA polymerase & [76] & $\mathrm{I}, 2,4,5$ & 34 & 33.9 \\
\hline $\mathrm{K} 4 \mathrm{~L}$ & Homolog to VP37, phoshoplipase D & {$[58,77]$} & 3,4 & 4 & 8.5 \\
\hline LIR & IMV membrane protein & [78] & $2,3,4,5$ & 8 & 40.8 \\
\hline L3L & unknown & & $1,2,4,5$ & 7 & 22.9 \\
\hline L4R & Major core protein & [79] & $1,2,3,4,5$ & 25 & 77.7 \\
\hline $\mathrm{O} 2 \mathrm{~L}$ & Glutaredoxin & {$[80,81]$} & $1,2,3,4,5$ & 7 & 70.4 \\
\hline
\end{tabular}


compromised people, and the complications associated with this live-attenuated vaccine.

Poxviruses, such as VV, are amongst the largest and most complex of the eukaryotic DNA viruses and are distinguished by replicating exclusively within the cytoplasmic compartment of infected cells [3]. VV regulates the expression of more than 250 viral gene products in a temporal fashion during the viral replicative cycle which results in at least four infectious forms all of which share the same intracellular mature virus (IMV) at their center which contains one membrane and a concave brick core. $\mathrm{VV}$ proteins are denoted by their corresponding open reading frame (ORF). The conventional designation of VV ORF consists of a Hind III DNA fragment (A-O), followed by the number of the ORF in that fragment (numbered left to right), and finally by the direction of the ORF (L or R).

Although the complete genome sequence of $\mathrm{VV}$ (strain Copenhagen) has been available for years [4], there has been little comprehensive proteomic analysis of the $\mathrm{VV}$ virion described so far. Jensen, et al. identified 13 major membrane and core proteins of the $\mathrm{VV}$ virion using 2-D gel electrophoresis followed by in-gel trypsin digests and peptide mass fingerprints for database searching [5]. Using a similar gel-based strategy, three major early proteins associated with the virosomes in VV-infected cells were identified by Murcia-Nicolas, et al. [6].

In this report we have utilized tandem mass spectrometry (MS) to analyze the protein composition of the vaccinia virion. A comprehensive proteome analysis of the protein composition of the $\mathrm{VV}$ virion represents an analytical challenge as there is no general analytical strategy available that is capable of identifying membrane and core proteins, low and high abundant proteins equally well. Therefore, we have used several analytical strategies to obtain a large number of high confidence protein identifications. Two different separation strategies [high performance liquid chromatography (HPLC) and sodium dodecyl sulfate-polyacrylamide gel electophoresis (SDSPAGE)] were combined with tandem mass spectrometry. In addition, a "shotgun" approach with no further separation was evaluated. For the tandem mass spectrometry, three different MS instruments were utilized: 1.) a matrix assisted laser desorption ionization tandem mass spectrometer with time-of-flight/time-of-flight optics (MALDI-TOF/TOF), 2.) a quadrupole-time of flight mass spectrometer (LC-ESI-Q-TOF), and 3.) a quadrupole ion trap mass spectrometer (LC-ESI-QIT); the latter two instruments were equipped with online HPLC and electrospray ionization interfaces [7]. In the process of analyzing the vaccinia virion, we have identified sixty three $\mathrm{VV}$ proteins, two of which have not been reported previously.

\section{Results \\ Viral fractionation}

In order to simplify our analytical strategy, we partitioned the vaccinia virion into two enriched fractions: a supernatant or membrane fraction containing the soluble proteins and a fraction enriched with the cores and insoluble proteins. The fractionation was assisted by incubating purified virions in the presence of a reducing agent and non-ionic detergent. Beta-octylglucopyranoside (OG) was chosen as the detergent for dissolving the membrane because in low amounts it does not adversely affect MS analysis, whereas, conventional detergents such as SDS and Triton X100 can greatly interfere with HPLC and mass spectrometric analysis [8]. We tested the efficiency of OG in separating the virion components and found that the supernatant and pellet banding patterns on an SDS-PAGE gel differ (Figure 1A and 1B). Subsequent analysis of this separation with immunoblot analysis using antibodies to L1R (membrane protein) and 4b (A10L, core protein) showed that each fraction was enriched with these proteins (data not shown). Due to the comprehensive nature of this study, no attempts were made to completely separate the soluble membrane proteins from the core proteins.

\section{Identification of $V V$ proteins}

Table 1 summarizes the results of our proteomic study. Tandem mass spectrometry yields peptide sequences, allowing the search of non-redundant protein databases to obtain high confidence protein identifications. In total, over 2716 tandem mass spectra were analyzed to yield sequence information for 595 non-redundant peptides. Peptides scores of 40 or greater were considered positive matches. In rare cases, tandem mass spectra that yielded scores 20 and 40 were analyzed manually. In order for a protein to be a "positive" we used the following criteria: 1.) identify greater than $5 \%$ of the protein sequence; 2 .) more than one peptide needed to be identified in a single method, or a single peptide needed to be identified at least with two different methods. Using these stringent conditions, sixty three different proteins were identified in the vaccinia virion. The total number of peptides found for each protein ranged from 1 to 62 (Table 1, column 5), and the total sequence coverage of the proteins ranged from $8.2 \%$ to $94.9 \%$ (Table 1 , column 6 ). Of the sixty three proteins identified, 2 are predicted gene products that have not been shown to be expressed before: E6R and L3L (Table 1, italicized).

\section{Method I: SDS-PAGE + LC-ESI-Q-TOF MS}

SDS-PAGE was employed to partition the core- and membrane-enriched fractions prior to MS analysis. The two protein fractions were resolved on a $12.5 \%$ SDS-PAGE gel and stained with Coomassie brilliant blue (Fig 1A and 1B). Each gel was sliced into several sections and each sec- 


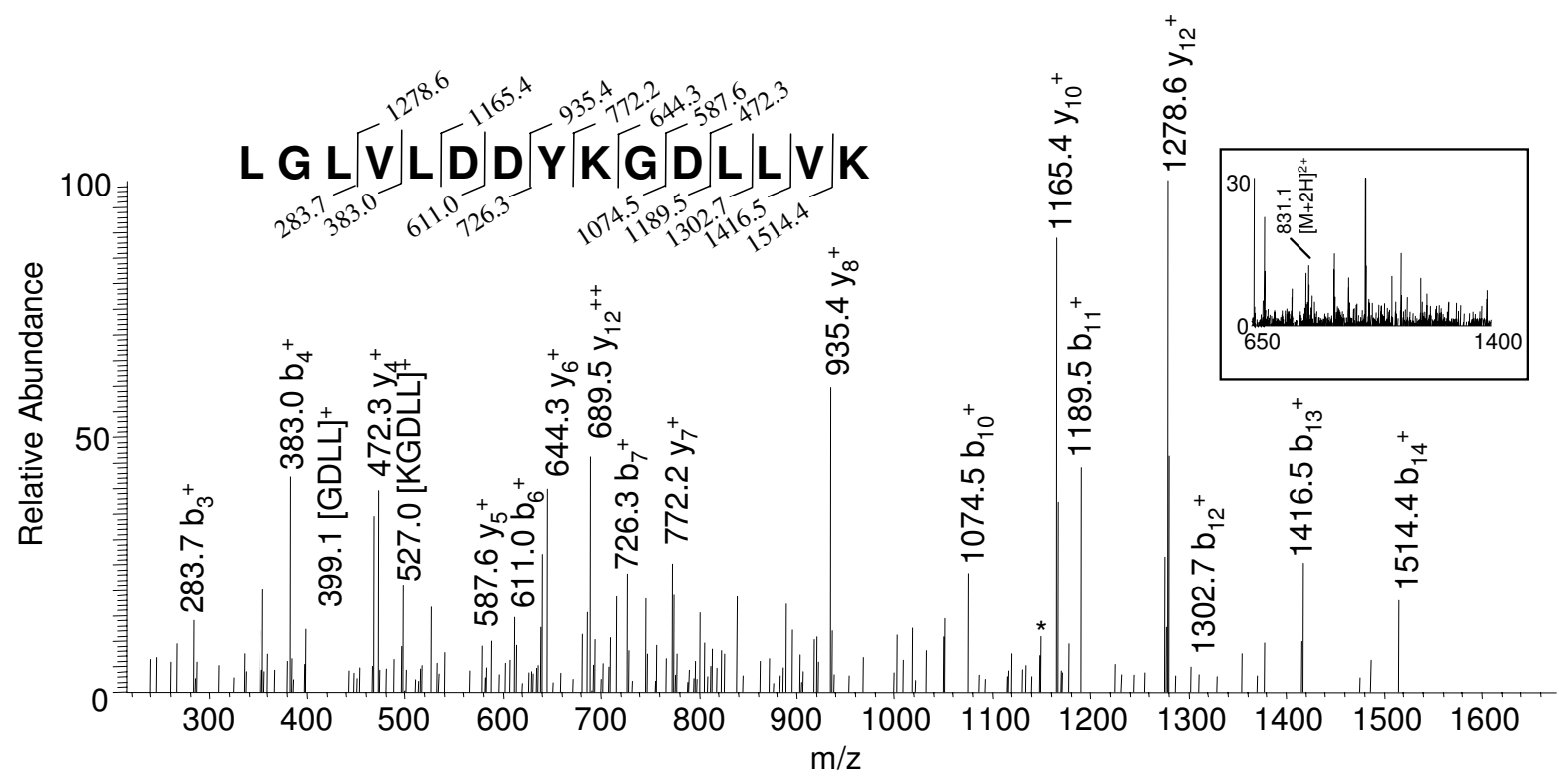

Figure 2

Mass analysis of a distinct peptide from the E6R protein using Method 2 (SDS-PAGE + LC-ESI-QIT MS) Gel slice "d" from the SDS-PAGE of the core-enriched fraction (Fig. IA) was subjected to an in-gel trypsin digestion, and analyzed by LC-ESI-QIT MS. The tandem mass spectrum data, correlating to the full scan mass spectrum (inset, doubly charged parent ion at $\mathrm{m} / \mathrm{z} 83 \mathrm{I} . \mathrm{I})$, reveals a peptide of the E6R protein. Asterisks $\left(^{*}\right)$ denote the loss of ammonia $\left(\mathrm{NH}_{3}\right)$ or water $\left(\mathrm{H}_{2} \mathrm{O}\right)$.

tion was subjected to in-gel trypsin digestion as described in the Methods section. The tryptic digests were analyzed by LC-ESI-Q-TOF MS. As a typical example of the kind of data used for peptide identification using MASCOT software, the tandem mass spectrum of a peptide originating from the major core protein, L4R, is shown in Figure 1C. This spectrum was obtained from the tryptic digest of gel slice "h" (Fig. 1B). The full scan mass spectrum shows a peak at $\mathrm{m} / \mathrm{z} 867.9$ which represents the doubly charged ion of a peptide with a molecular mass of 1733.8 Da. Tandem MS of the doubly charged ion at $\mathrm{m} / \mathrm{z} 867.9$ yielded a fragment ion spectrum displaying eleven C-terminal (ytype) fragment ions and one N-terminal (b-type) fragment ion. Database searching of this tandem mass spectrum identified this peptide as ELESYSSSPLQEPIR, the partial sequence (amino acid [aa] 213-227) of the L4R protein. This tandem mass spectrum obtained the excellent score of 129 . Using this method we obtained 708 spectra, observed 315 peptides and identified 52 proteins.

\section{Method 2: SDS-PAGE + LC-ESI-QIT MS}

The tryptic digestions from the excised gel slices were additionally analyzed on an ion trap mass spectrometer (LC-ESI-QIT). Using this platform we identified 53 virion proteins from 1088 spectra corresponding to 417 total peptides. For example, during the mass spectrometric analysis of the tryptic digest of gel slice "d" (Fig. 1A) an ion peak at $\mathrm{m} / \mathrm{z} 831.1$ in the full scan mass spectrum was observed (Fig. 2C inset) which corresponds to a doubly charged ion of a peptide with molecular mass 1660.2 Da. The tandem MS of the double charged ion had a good score of 62 and revealed the sequence for a peptide of the E6R protein, LGLVLDDYKGDLLVK (aa 470-484). Seven C-terminal fragment ions, nine $\mathrm{N}$-terminal fragment ions, and two internal fragments ions (m/z 399.1 [GDLL] and $\mathrm{m} / \mathrm{z} 527.0$ [KGDLL]) were observed for this particular peptide. E6R is a vaccinia protein that has not been previously reported.

\section{Method 3: HPLC + LC-ESI-QIT MS}

We also employed reverse phase HPLC to fractionate the proteins prior to MS analysis (Fig. 3A is the enriched core fraction and Fig. $3 \mathrm{~B}$ is the enriched membrane fraction). HPLC separation was well suited for fractionating the soluble proteins, but proved to be more challenging for the insoluble core proteins. The cores did not completely dissolve even when treated with sodium deoxycholate. Approximately $200 \mu \mathrm{L}$ of sample (as described in the Methods section) was loaded onto a $2 \times 150 \mathrm{~mm} \mathrm{C}_{4}$ reverse phase column, and fractions were collected manu- 

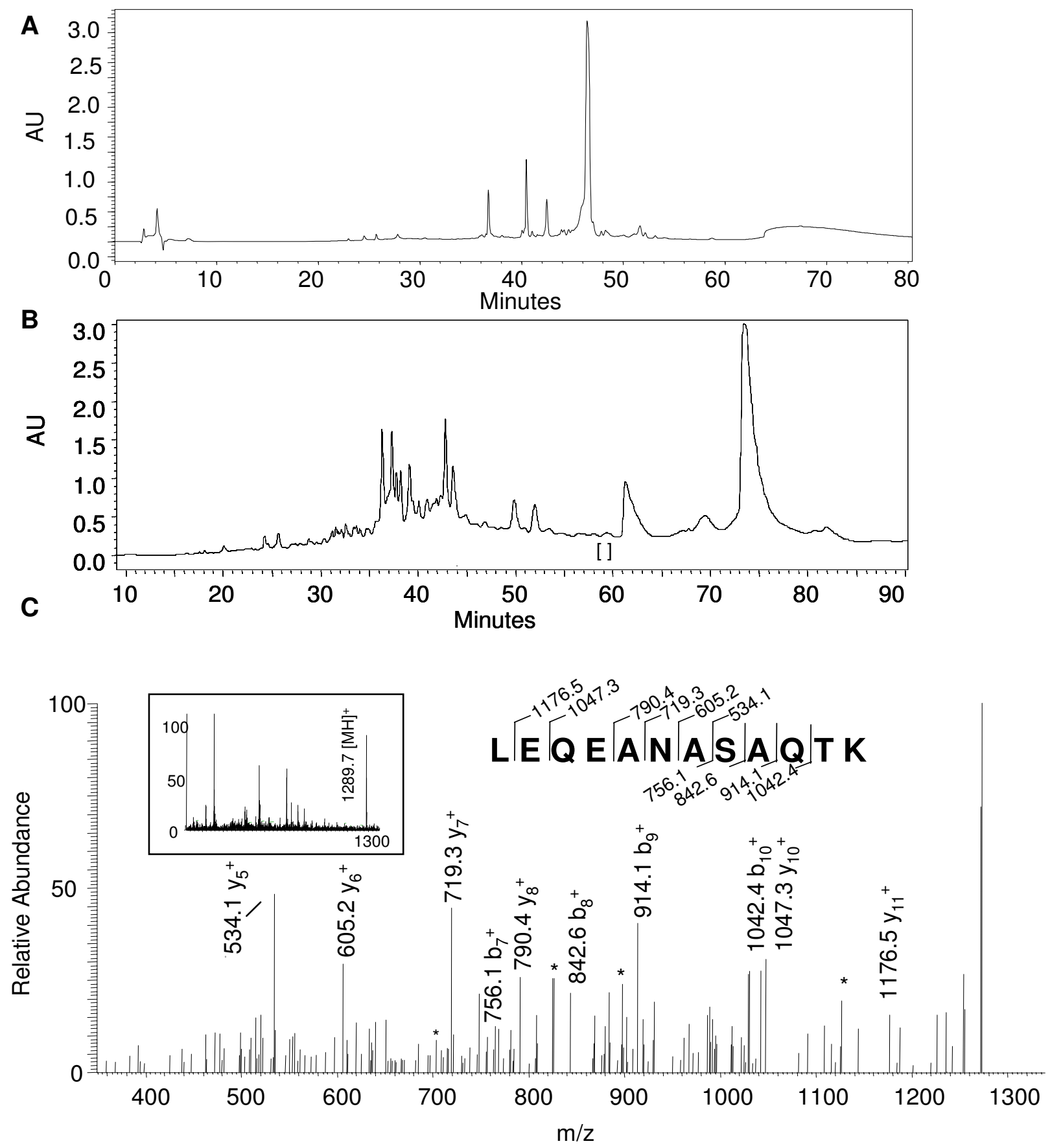

Figure 3

Mass analysis of a distinct peptide from the LIR protein using Method 3 (HPLC + LC-ESI-QIT MS). The core(A) and membrane-enriched (B) fractions were resolved on a $C_{4}$ HPLC column according to the Methods section. Tandem mass spectrometric analysis of fraction 59-60 (B, indicated by brackets) produced from a singly charged precursor ion (inset, $\mathrm{m} / \mathrm{z}$ I 289.7), yielded fragment ions which corresponded to a peptide the LIR protein. Asterisks $\left({ }^{*}\right)$ denote the loss of ammonia $\left(\mathrm{NH}_{3}\right)$ or water $\left(\mathrm{H}_{2} \mathrm{O}\right)$. 


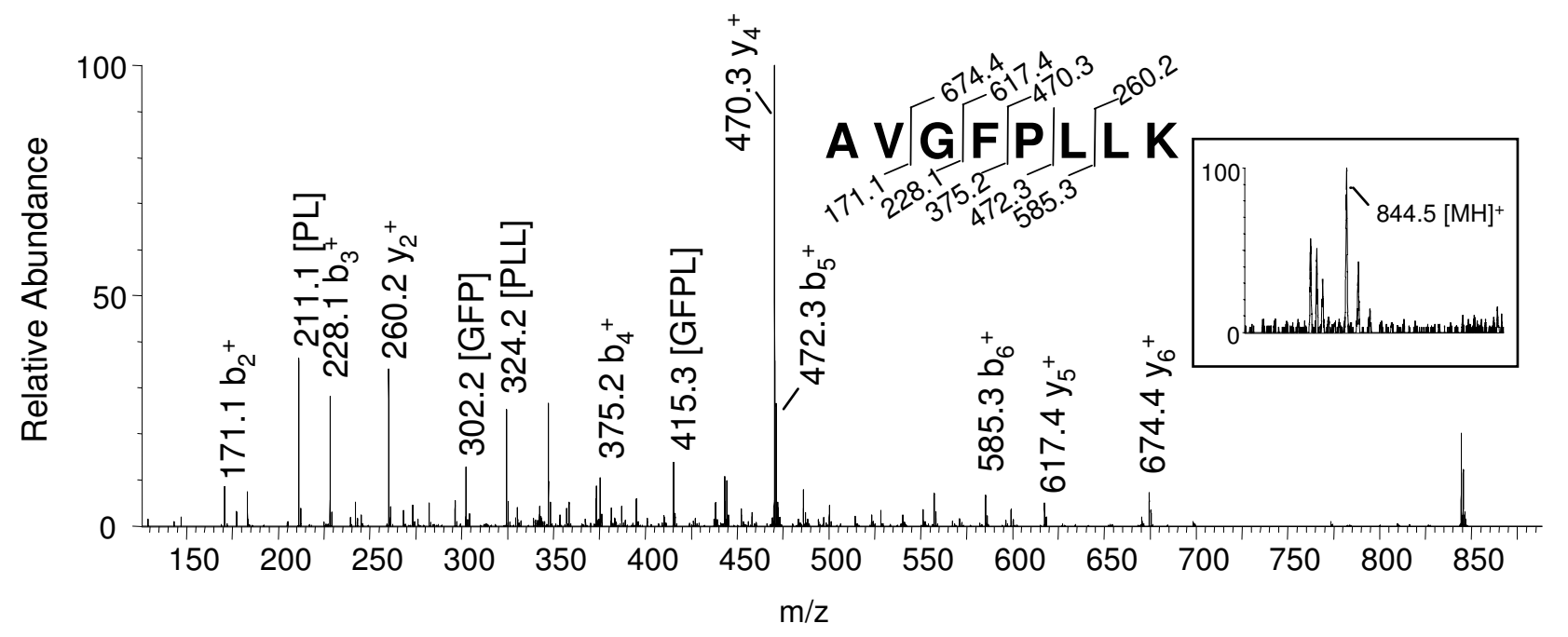

\section{Figure 4}

Mass analysis of a distinct peptide from the L3L protein using Method 4 (LC-ESI-Q-TOF MS). The core-enriched fraction of the virion was subjected to trypsin digestion, and analyzed by the LC-ESI-Q-TOF mass spectrometer. The full scan mass spectrum displays a peak at $\mathrm{m} / \mathrm{z} 844.5$ (inset), and corresponding tandem mass spectrum identifies a peptide of the L3L protein. Four internal fragments were also identified for the L3L peptide including: PL, GFP, PLL, and GFPL.

ally every 2 minutes between 20 and 80 minutes. Each of these fractions was subjected to trypsin digestion prior to analysis by LC-ESI-QIT MS. Using this method we obtained 367 tandem mass spectra that correlated to 131 total peptides yielding 25 distinct vaccinia virion proteins. A representative example is shown in Figure $3 \mathrm{C}$. The membrane sample at 59-60 minutes (Fig. 3B, brackets) underwent tandem mass spectrometric analysis to reveal a peptide of the well characterized L1R protein. The full scan spectrum for this fraction contained an ion at $\mathrm{m} / \mathrm{z}$ 1289.7 (Fig. 3C, inset) which was used for tandem mass spectrometry. The fragment ions observed matched the theoretical fragmentation pattern for a peptide of the L1R protein (Fig. 3C) encompassing the sequence LEQEANASAQTK, aa 22-33. The ions at $\mathrm{m} / \mathrm{z} 534.1,605.2,719.3$, 790.4, 1047.3, and 1176.5, are the C-terminal fragment ions, while the ions at $\mathrm{m} / \mathrm{z} 756.1,842.6,914.1$, and 1042.4 are the $\mathrm{N}$-terminal fragments. This spectrum received an acceptable score of 47 .

\section{Method 4: LC-ESI-Q-TOF MS}

We wanted to analyze the samples without pre-fractionation to compare the data with thegel fractions (method 1 \& 2) and HPLC fractions (method 3). Known as a "shotgun" approach, the membrane- and core-enriched fractions were directly digested with trypsin, and analyzed using LC-ESI-Q-TOF MS. This methodology resulted in
319 tandem mass spectra that matched 202 total peptides, and identified 53 virion proteins. One exciting example is the L3L protein (Fig. 4), a protein that has not been reported before. When the parent ion at $\mathrm{m} / \mathrm{z} 844.5$ (Fig. 4, inset) was fragmented, four C-terminal, five $\mathrm{N}$-terminal, and four internal fragment ions (m/z 211.1, 302.2, 324.2, and 415.3 ) were observed. The respective tandem mass spectrum had a score of 59 . This data was assigned to the sequence AVGFPLLK (aa 115-122) of the L3L protein.

\section{Method 5: MALDI-TOFITOF MS}

Direct trypsin digests of the membrane- and core-enriched fractions were also analyzed using MALDI-TOF/TOF MS to take advantage of complementary ionization techniques [7]. MALDI tandem mass spectrometry generated 234 spectra, correlating to 209 total peptides, and resulting in 55 unique virion protein identifications. Of particular interest is the ion at $\mathrm{m} / \mathrm{z}$ at 1522.69 in the full scan mass spectrum (Fig. 5, inset). Tandem mass spectral analysis of this ion revealed the peptide HTFNLYDDNDIR, the partial sequence (aa 90-101) of the G3L protein. The tandem mass spectral analysis yielded six C-terminal, and 4 N-terminal fragment ions (Fig. 5), and obtained an average score of 41 . 


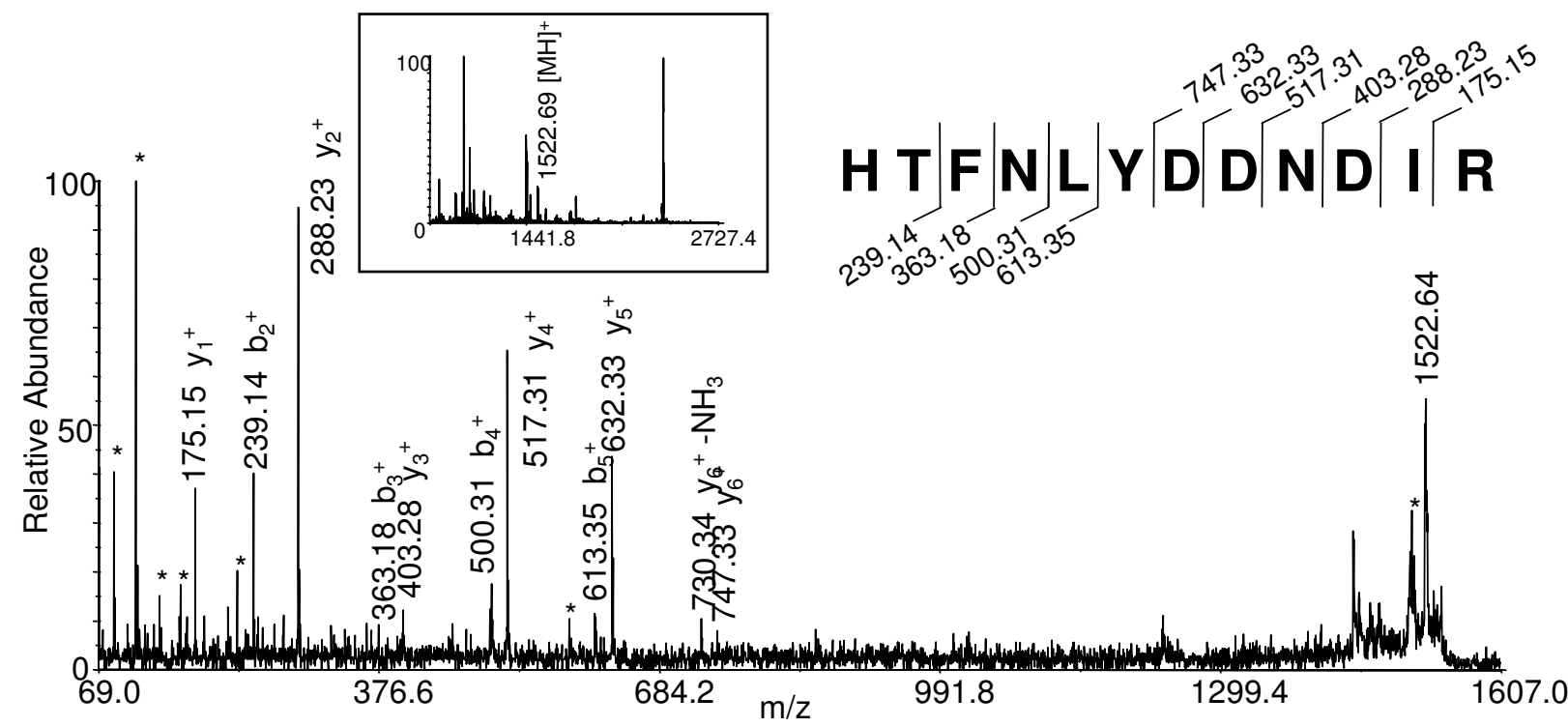

\section{Figure 5}

Mass analysis of a distinct peptide from the G3L protein using Method 5 (MALDI-TOF/TOF). The membraneenriched fraction of the virion was subjected to trypsin digest, and analyzed by MALDI-TOF/TOF MS. The full scan mass spectrum yielded a singly charged ion at $\mathrm{m} / \mathrm{z} 1522.69$ (inset). Tandem mass spectrum of the parent ion corresponds to a peptide of G3L. Asterisks $(*)$ denote the loss of ammonia $\left(\mathrm{NH}_{3}\right)$ or water $\left(\mathrm{H}_{2} \mathrm{O}\right)$.

\section{New vaccinia virus proteins}

This comprehensive study of the vaccinia virion revealed two newly observed proteins. Each of these proteins (E6R and L3L) has not been described previously. The peptides detected for each of these proteins are listed in Tables 2 and 3 .

The E6R ORF is situated between the E5R and E7R genes and produces a 567 amino acid protein. The predicted molecular mass and pI of E6R is 66,670 Da and 6.16, respectively. E6R was identified in fraction " $\mathrm{d}$ " of figure 1A, which corresponds to its predicted molecular weight. Blast searches revealed high homology to orthopoxvirus proteins [9]. Hydrophobicity plots revealed no specific region of interest [10]. We observed 19 peptides from the E6R protein with a confidence scoring range of 17-85. The identified peptides covered $43.1 \%$ of the protein (Table 2).

We observed 7 peptides for L3L covering $22.9 \%$ of the sequence (Table 3 ). The $\mathrm{L} 3 \mathrm{~L}$ protein has a predicted molecular mass of $40.6 \mathrm{kDa}$ (350 amino acids), and a predicted pI of 8.91. Its ORF is situated between the L2R and L4R genes. This protein was identified in fraction " $e$ " and "f" of Figure 1A. Only poxvirus proteins had homology to the L3L sequence resulting from Blast searches [9], and hydrophobicity plots revealed no specific region of interest [10].
Both proteins were found in samples from the coreenriched fractions of Method 1, 2, 4, and 5. No peptides from either protein were found in the membraneenriched fractions.

\section{Discussion}

The goal of this study was to obtain a comprehensive proteomic analysis of the Copenhagen strain of the vaccinia virus virion. This strain of $\mathrm{VV}$ was chosen because it is an important model strain for variola, and it has been completely sequenced.

One concern we had was that the predominant proteins would eclipse the smaller or less abundant proteins when analyzed by MS. In order to overcome this problem we fractionated the virion into soluble (membrane) and insoluble (core) fractions via treatment with detergent and centrifugation. Further fractionation was achieved using two procedures: SDS-PAGE and HPLC. The resolution of viral proteins by SDS-PAGE followed by in-gel trypsin digestion of gel slices and tandem mass analysis (LC-ESI-QIT MS) for protein identification had been used successfully before on other VV proteins [11]. A second $\mathrm{MS}$ analysis was done in parallel with these samples using LC-ESI-Q-TOF MS. Although both instruments use the same ionization techniques, the mass analyzers are different. Both mass spectrometers identified 49-52 proteins using this procedure, however, the proteins identified dif- 
Table 2: Amino acid sequence of the VV protein E6R and identified peptides Peptides detected from the Method I (SDS-PAGE + LCESI-Q-TOF MS), Method 2 (SDS-PAGE + LC-ESI-QIT MS), Method 3 (HPLC + LC-ESI-QIT MS), Method 4 (LC-ESI-Q-TOF MS), and Method 5 (MALDI-TOF/TOF MS) are denoted with an asterisk (*). Peptides that are in bold print have been identified by at least one of the five methods.

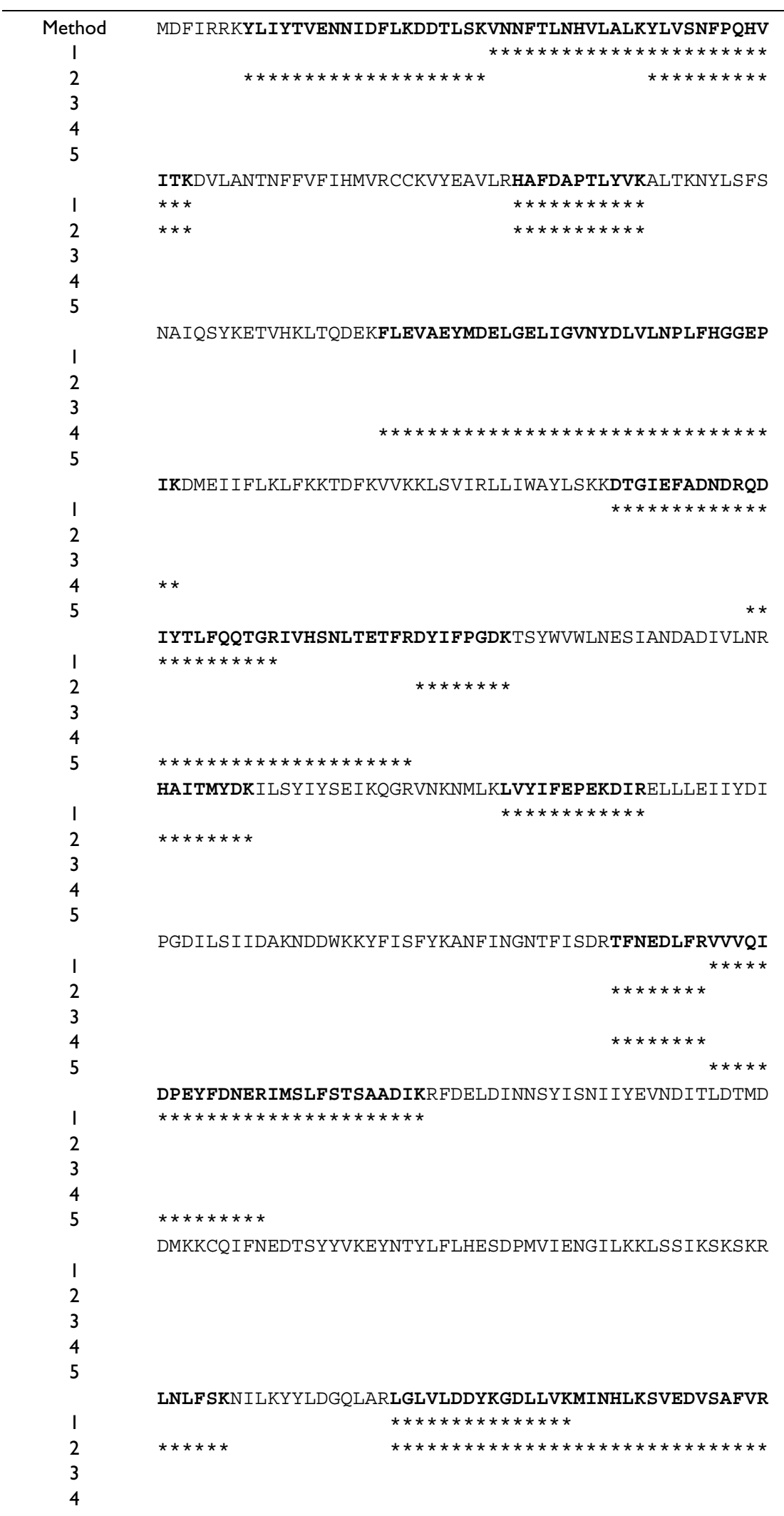


Table 2: Amino acid sequence of the VV protein E6R and identified peptides Peptides detected from the Method I (SDS-PAGE + LCESI-Q-TOF MS), Method 2 (SDS-PAGE + LC-ESI-QIT MS), Method 3 (HPLC + LC-ESI-QIT MS), Method 4 (LC-ESI-Q-TOF MS), and Method 5 (MALDI-TOF/TOF MS) are denoted with an asterisk (*). Peptides that are in bold print have been identified by at least one of the five methods. (Continued)

\begin{tabular}{lc}
\hline 5 & FSTDKNPSILPSLIKTILASYNISIIVLFQRFLRDNLYHVEEFLDKSIHL \\
1 & \\
2 & \\
3 & \\
4 & \\
5 & \\
1 & \\
2 & \\
3 & \\
4 & \\
5 & \\
\hline
\end{tabular}

fered (Fig. 6). Complementary to SDS-PAGE for protein fractionation, reverse phase HPLC was used (Method 3). Due to the encountered difficulties with the insolubility of the viral cores, only the major core proteins were identified (A3L and $\mathrm{A} 10 \mathrm{~L})$ from the core-enriched fraction, resulting in a low total number of proteins identified with this procedure (25 versus $49-54$ for the other methods, Fig. 6). Support for this notion is obtained by the study reported by Zachertowska, et al. in which the pooling of fractions from 5 HPLC runs resulted in the identification of only 6 proteins of the myxoma virion [12]. Recognizing this limitation we utilized multiple methods to obtain a more comprehensive catalog of the virion constituents. In order to complete this study, we felt it important to analyze the membrane- and core-enriched samples without separation prior to trypsin digestion. We used two different mass spectrometers to analyze the in-solution digests: MALDI-TOF/TOF MS and LC-ESI-Q-TOF MS. This "shotgun" strategy resulted in a lower number of total spectra and identified a lower number of peptides, but yielded a comparable number of protein identifications ( 54 and 52, respectively, Fig. 6).

A summary of the number of proteins found versus the method used to detect them is shown in Figure 6. There is a high degree of overlap between the methods; noteworthy is that 15 proteins were identified by all 5 methods. Another 20 proteins were identified using methods 1, 2, 4, and 5; this is most likely due to the lack of data for the core-enriched fraction using the HPLC pre-separation procedure (method 3 ). The majority of the $\mathrm{VV}$ proteins identified in this study were observed in 3 or more methods $(85.7 \%)$, underscoring the complementarity of the different approaches used.

The current functional annotation of the VV genome is described in the following articles: a minireview by Pao- letti, et al [4], describing an update on the vaccinia genome, and the Poxviridae chapter in Fields Virology written by Bernard Moss [3]. Both of these articles describe the organization of the entire genome of the vaccinia virion, and the known functionality of the various vaccinia proteins. Moss describes there being 47 known ORFs that express proteins of the vaccinia virion including membrane proteins as well as core constituents. It is interesting to note that we found 41 of the known virion components. Of the 25 non-enzymatic components only one was not identified - the D13L protein which has been linked to rifampicin resistance. Of the 22 enzymatic virion components 17 were identified in this study. Two of the missed proteins include D7R and G5.5R which are the two smallest subunits of the RNA polymerase. Although these two components were not identified, the other six RNA polymerase subunits were identified (A5R, A24R, A29L, E4L, J4R and J6R). The remaining three known virion enzymes that were not identified in this study include: A18R (DNA-dependent ATPase), B1R (Protein Kinase 1) and H6R (DNA Topoisomerase 1). Several factors might contribute to the lack of data for these proteins including: the size of the protein, the hydrophobicity of a protein, and the absolute amount of a protein in the virion. In general, very hydrophobic proteins and low abundance proteins are commonly underrepresented in proteomic-type studies. Also, very small proteins are frequently missed. In an effort to overcome at least in part these inherent limitations of comprehensive proteomic studies, we combined different protein fractionation methods with "shotgun" approaches. In addition, to ensure that the highest level of confidence for peptide identification and protein coverage for the current study, the "shotgun" digests were analyzed by two different ionization techniques, ESI and MALDI, taking advantage of the complementarity of these ionization techniques [7]. 
Table 3: Amino acid sequence of the VV protein L3L and identified peptides Peptides detected from the Method I (SDS-PAGE + LCESI-Q-TOF MS), Method 2 (SDS-PAGE + LC-ESI-QIT MS), Method 3 (HPLC + LC-ESI-QIT MS), Method 4 (LC-ESI-Q-TOF MS), and Method 5 (MALDI-TOF/TOF MS) are denoted with an asterisk (*). Peptides that are in bold print have been identified by at least one of the five methods.

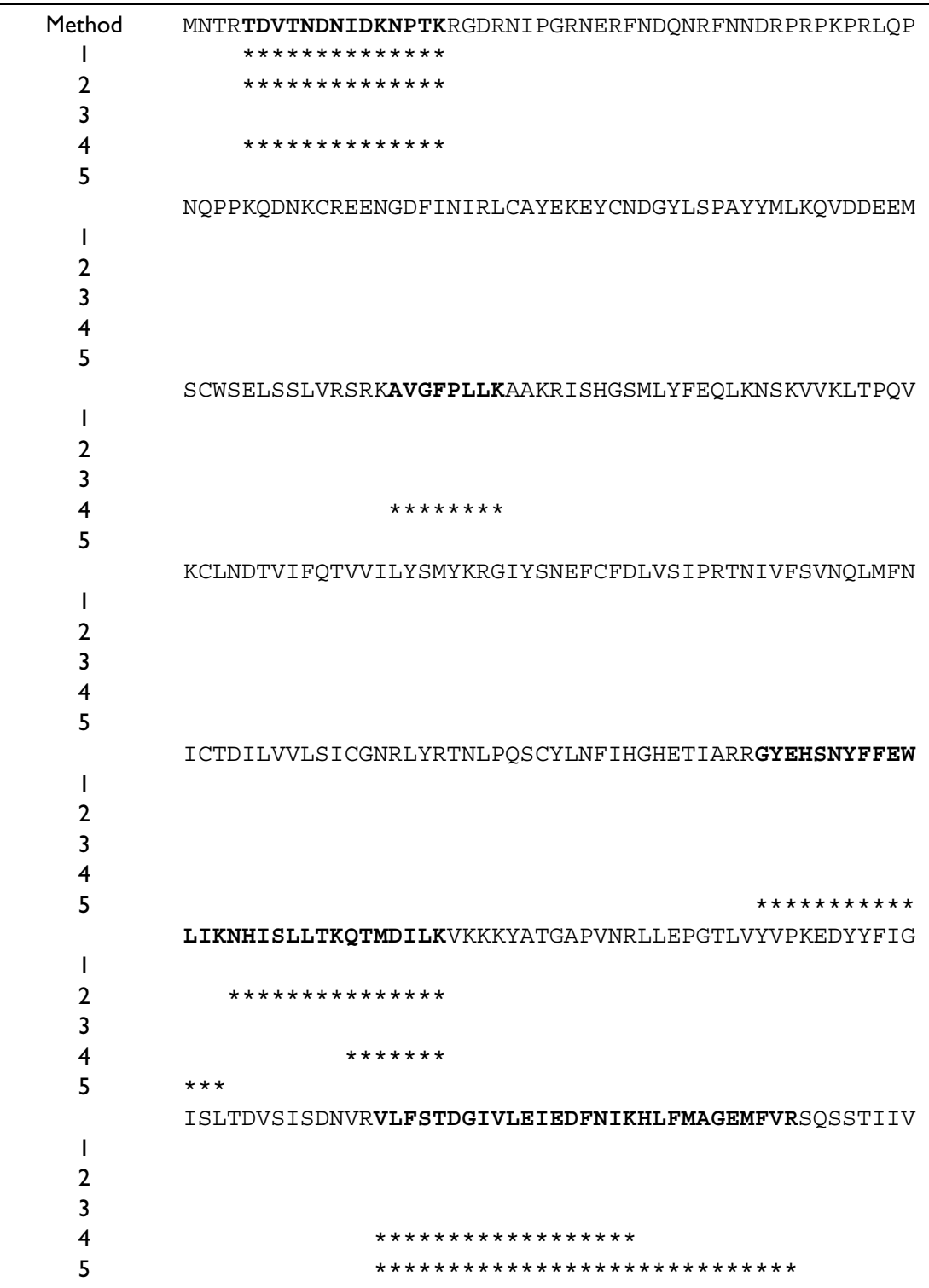

Some recently reported proteins that have been shown to be associated with the core include: A15L, A30L, E11L, G1L, G7L, H1L and J1R - all of which were identified in our analysis. We also found membrane proteins (F9L, F10L, and E8R) and cytosolic proteins (A16L, E10R, F8L, $\mathrm{G} 4 \mathrm{~L}$, and $\mathrm{I} 3 \mathrm{~L}$ ). The remaining proteins identified by this study included A42R, A46R, B22R, E3L, and K4L. The types of $\mathrm{VV}$ proteins identified in this study are summarized in Figure 7.

\section{Conclusion}

This study represents the first steps toward a widespread identification of the viral protein constituents that make up the structurally complex $\mathrm{VV}$ virion. Although not quantitative, this approach has confirmed the presence of most known virion proteins and identified new viral proteins for the first time. Defining the $\mathrm{VV}$ proteome is a significant scientific challenge but successful completion of this goal will be useful for understanding the biology of orthopoxviruses.

\section{Methods \\ Materials}

Media and supplements were purchased from Invitrogen (Carlsbad, CA). Dithiothreitol (DTT), Tris, N-ethylmorpholine, trifluoroacetic acid (TFA), formic acid, $\alpha$-cyano- 


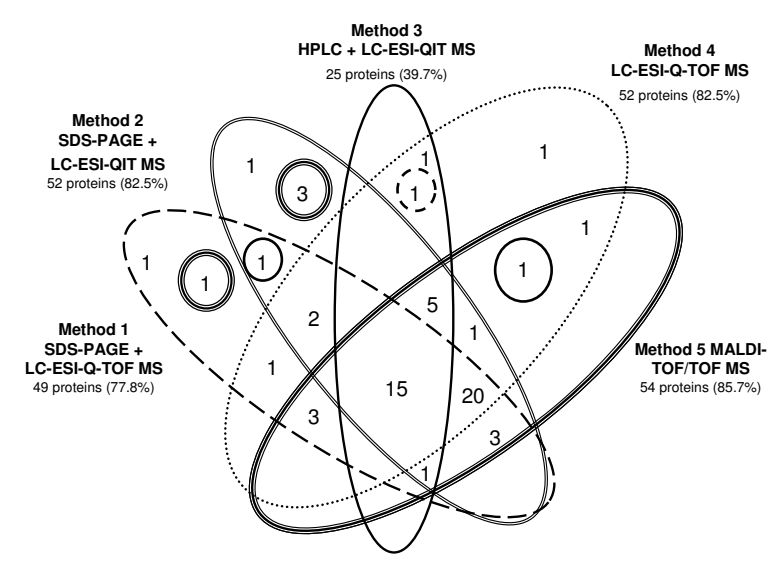

\section{Figure 6}

Diagram of proteins identified using multiple methods. All overlaps are shown for all five methods: Method I SDS-PAGE + LC-ESI-Q-TOF MS (dashed line); Method 2 SDS-PAGE + LC-ESI-QIT MS (double line); Method 3 -HPLC + LC-ESI-QIT MS (solid line); Method 4 - LC-ESI-Q-TOF MS (dotted line); and Method 5 - MALDI-TOF/TOF (triple line). Numbers represent the number of shared proteins in overlapping areas. The total number of proteins identified for the method and the percent of total proteins identified is listed.

4-hydroxycinnamic acid (HCCA), guanidine hydrochloride and $\beta$-Octylglucopyranoside (OG) were purchased from Sigma (St. Lois, MO). HPLC grade acetonitrile (AcN) was purchased from Fisher Scientific (Pittsburg, PA) and the lyophilized sequencing-grade trypsin from Promega (Madison, WI). General use water was generated by a Milli-Q water purification system (Millipore, Bellerica, MA)

\section{Virion purification and fractionation}

Vaccinia virus (Copenhagen strain) was propagated as described by Hruby et al [13], and modified in the following way: ten $150 \mathrm{~mm}$ dishes of $80 \%$ confluent $\mathrm{BSC}_{40}$ cells were infected at a multiplicity of infection of 0.1 plaque forming units (pfu)/cell. The infected cells were harvested and subjected to homogenization. Purified virus was obtained through a side-band-pull from a buoyant sucrose density gradient. This purified virus was pelleted by centrifugation. To obtain the membrane- and coreenriched fractions, a protocol from Spencer, et al [14] was modified. The equivalent of three tubes (or thirty $150 \mathrm{~mm}$ dishes) was resuspended in $300 \mu \mathrm{L}$ of buffer $(0.8 \%$ OG, $50 \mathrm{mM}$ DTT, $50 \mathrm{mM}$ Tris, $\mathrm{pH}=8.4$ ). The three tubes containing the pelleted virus were rinsed with another $300 \mu \mathrm{L}$ of buffer. The total $600 \mu \mathrm{L}$ was placed in an incubator shaker (New Brunswick, Innova 4300, Edison, NJ) for 1.25 hours, shaking at $200 \mathrm{rpm}$ at $37^{\circ} \mathrm{C}$. The sample was centrifuged at $15,000 \times \mathrm{g}$ at $4^{\circ} \mathrm{C}$ for $15 \mathrm{~min}$. The supernatant containing the enriched membrane fraction was extracted leaving the pellet (enriched core fraction) intact.

\section{HPLC (membrane-enriched fraction)}

The sample was transferred into a dialysis cassette (Pierce, Slide-A-Lyzer, 3,500 Da molecular weight cut off, MWCO) and dialyzed against $800 \mathrm{~mL}$ of $20 \mathrm{mM}$ Tris $(\mathrm{pH}=8.0)$ for 2 hours at room temperature, and changed three times. The final dialysis was performed for 16 hours at $4{ }^{\circ} \mathrm{C}$. Dialysis was performed to remove as much of the OG as possible. The sample was removed from the cassette, reduced to $500 \mu \mathrm{L}$ using a speed-vac, and filtered through a $0.2 \mu$ syringe filter. The sample was injected onto an HPLC (Waters Breeze system, Milford, MA) using a $500 \mu \mathrm{L}$ sample loop. A $5 \mu \mathrm{m} \mathrm{C}_{4} 300 \AA 2 \times 150 \mathrm{~mm}$ column (Phenomenex Jupiter, Torrance, CA) was used with a flow rate of $0.2 \mathrm{~mL} / \mathrm{min}$. A wavelength absorbance detector (Waters 2487 Dual Absorbance, Milford, MA) was used to detect wavelengths at 214 and $254 \mathrm{~nm}$. Solvent $A$ was composed of $5 \% \mathrm{AcN}, 0.05 \%$ TFA in $\mathrm{H}_{2} \mathrm{O}$ and solvent B was composed of $95 \%$ AcN, $0.05 \%$ TFA in $\mathrm{H}_{2} \mathrm{O}$. For the membrane-enriched sample the gradient system consisted of $10 \mathrm{~min}$ isocratic gradient with $98 \%$ of solvent A, 55 min gradient to $2 \% \mathrm{~A}$, and $10 \mathrm{~min}$ isocratic gradient with $2 \%$. Fractions were collected in 5 minute intervals for the first $20 \mathrm{~min}$ and then in $2 \mathrm{~min}$ intervals for $60 \mathrm{~min}$. The final $7 \mathrm{~min}$ was collected in one final fraction. A speed-vac was used to decrease the volume of the fractions to about $5-10 \mu \mathrm{L}$. The $\mathrm{pH}$ was adjusted with $50 \mathrm{mM}$ Tris ( $\mathrm{pH}=9.6$ ) or N-ethylmorpholine to between 7.0 and 8.5. For the trypsin digest $1.5 \mu \mathrm{L}$ of trypsin $(1 \mu \mathrm{g} / \mu \mathrm{L}$, Promega, Madison, WI) was added to each fraction. The fractions were incubated overnight at $37^{\circ} \mathrm{C}$.

\section{HPLC (core-enriched fraction)}

The core-enriched fraction was dissolved prior to injection on the HPLC [12]. Briefly, this was carried out by resuspending the insoluble pellet from the virion fractionation in $0.4 \%$ sodium deoxycholate and $10 \mathrm{mM}$ Tris, $\mathrm{pH}=9.0$, and incubating at $56^{\circ} \mathrm{C}$ for $10 \mathrm{~min}$. The sample was filtered and injected onto the HPLC system as described above. For the core-enriched sample the gradient system consisted of a $10 \mathrm{~min}$ isocratic gradient with $98 \%$ of solvent $\mathrm{A}, 40$ min gradient to $25 \% \mathrm{~A}, 30 \mathrm{~min}$ gradient to $2 \%$ $\mathrm{A}$, and a $10 \mathrm{~min}$ isocratic gradient with $2 \% \mathrm{~A}$. Fractions were collected as outlined above.

\section{SDS-PAGE}

Virion fractions were mixed with equal amounts of SDSPAGE loading buffer and resolved on SDS-PAGE gels $(12.5 \%)$ [15]. The protein bands were visualized using a filtered Coomassie stain (40\% methanol, 10\% acetic acid and $0.2 \%$ Coomassie brilliant blue R-250). Protein bands were excised and the preparation for in-gel digestion [16] 


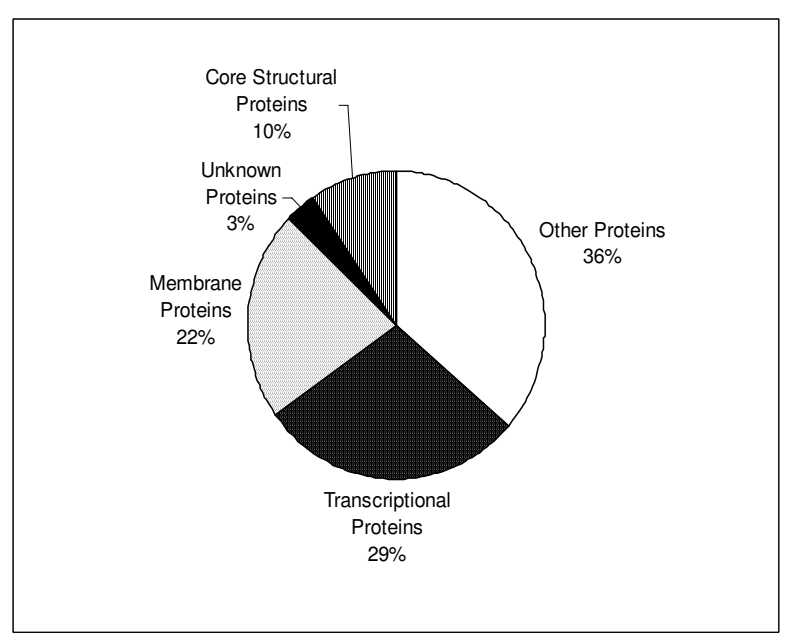

Figure 7

Summary of the functions of the 63 identified VV proteins. This graph summarizes the $63 \mathrm{VV}$ proteins identified in this study according to their function. These include: core structural proteins (A3L, A4L, AIOL, AI2L, AI4L, and L4R), membrane proteins (AI3L, AI7L, A27L, A33R, A34R, A56R, B5R, D8L, F9L, FI3L, H3L, H5R, JIR, and LIR), transcriptional proteins (A5R, A7L, A24R, A29L, DIR, D6R, DIIL, DI2L, EIL, E3L, E4L, H4L, IIL, I8R, J3R, J4R, J6R, and $\mathrm{K} 4 \mathrm{~L}$ ), proteins with other functions (AI5L, AI6L, A30L, A42R, A46R, B22R, D2L, D3R, E8R, EIOR, EI IL, F8L, FIOL, FI7R, GIL, G3L, G4L, G7L, HIL, I3L, I5L, I7L, and O2L), and the unknown proteins (E6R and $L 3 L$ ).

was as follows: sample bands from coomassie stained were manually excised, and placed in $0.5 \mathrm{~mL}$ Eppendorf tubes. The gel pieces were de-stained with acetic acid:ethanol: $\mathrm{H}_{2} \mathrm{O}$ in a 1:3:6 (v/v/v) ratio for 12-16 hours under gentle agitation. The gel slices were dehydrated with $\mathrm{AcN}$ (vortexed for $10 \mathrm{~min}$ ), and re-hydrated with $50 \mathrm{mM}$ ammonium bicarbonate (vortexed for $10 \mathrm{~min}$ ). This procedure was repeated twice, and a final dehydration was performed with AcN. After vortexing any remaining liquid was removed by pipette and the gel slices were dried with a speed vac for 5 minutes.

\section{In-gel trypsin digestion}

To each tube containing gel slices $10-40 \mu \mathrm{L}$ of $20 \mu \mathrm{g} / \mu \mathrm{L}$ Promega trypsin in $25-50 \mathrm{mM}$ Tris- $\mathrm{HCl}, \mathrm{pH}=8.0$ was added. The tubes were incubated on ice for 35-40 min. After the enzyme solution was fully absorbed, the excess solution was removed and replaced with $10 \mathrm{mM}$ Tris- $\mathrm{HCl}$, $\mathrm{pH}=8.0$, enough to fully cover each gel slice. Each sample was incubated at $37^{\circ} \mathrm{C}$ for $12-16$ hours. Any nonabsorbed solution was placed in a new tube. The peptides were extracted from the gel by vortexing with $30-70 \mu \mathrm{L}$ of $50 \% \mathrm{AcN} / 5 \%$ formic acid. The extraction fluid was added to the previously removed non-absorbed solution and concentrated to $10-15 \mu \mathrm{L}$.

\section{In-solution trypsin digestion}

Samples from the HPLC or from the membrane-enriched fraction were subjected to in-pot trypsin digest by adding a 1:7 ratio of enzyme $(1 \mu \mathrm{g} / \mu \mathrm{L})$ :protein and incubating at $37^{\circ} \mathrm{C}$ for $12-16$ hours. Because the core-enriched fraction contained an intact protein "shell" the following was conducted in order to solubilize the proteins for trypsin digestion. The pellet from the virion fractionation was resuspended in $200 \mu \mathrm{L}$ of $50 \mathrm{mM}$ Tris $(\mathrm{pH}=8.4)$, and $6 \mathrm{M}$ guanidine $\mathrm{HCl}$. This solution was brought to $90^{\circ} \mathrm{C}$ for 5 minutes, and after the protein was dissolved, the mixture was diluted with $2.8 \mathrm{~mL}$ of $\mathrm{H}_{2} \mathrm{O}$. Dialysis was performed with a Slide-A-Lyzer (3,500 MWCO) membrane against $800 \mathrm{~mL}$ of $20 \mathrm{mM}$ Tris- $\mathrm{HCl}(\mathrm{pH}=8.0)$. The buffer was changed 3 times in 24 hours. As the guanidine $\mathrm{HCl}$ dialyzed out of the protein solution the proteins precipitated resulting a fluffy white precipitate. However, when this solution was treated with trypsin (as outlined above) the precipitate dissolved indicating that the trypsin cleaved the proteins into various peptides.

\section{LC-ESI-QIT MS}

An electrospray ionization quadrupole ion trap mass spectrometer (Finnigan LCQ, San Jose, CA) equipped with a Waters (Milford, MA) 515 HPLC system and LC Packings Accurate Flow Splitter was used. Ten microliters of the tryptic digest was loaded on a $\mathrm{C}_{18}$ trap and a $\mathrm{C}_{18}$ column $(0.17 \times 10 \mathrm{~mm}$, Jupiter $5 \mu, 300 \AA$, packed in-house $)$. HPLC was performed with a gradient from $90 \%$ solvent $A$ (0.1\% formic acid, $0.005 \%$ TFA, in 5\% AcN) to $90 \%$ solvent $\mathrm{B}(0.1 \%$ formic acid, $0.005 \% \mathrm{TFA}$ in $95 \% \mathrm{AcN})$ over 60 minutes. The full mass spectra (m/z 400 to 2000) and tandem MS (m/z 200 to 2000) spectra were acquired alternately with a dynamic exclusion of $1 \mathrm{~min}$ and the peptide was excluded for $1.5 \mathrm{~min}$.

\section{LC-ESI-Q-TOF MS}

Five microliters of the tryptic digest sample was mixed with $5 \mu \mathrm{L}$ of solvent A $(0.1 \%$ formic acid, $0.005 \%$ TFA, and $3 \% \mathrm{AcN}$ in $\mathrm{H}_{2} \mathrm{O}$ ). Five microliters of this solution was loaded for mass analysis. The HPLC was performed on a Waters CapLC system with a flow rate of $300 \mathrm{~nL} / \mathrm{min}$ in conjunction with a Symmetry 300, $\mathrm{C}_{18}, 5 \mu \mathrm{m}$ trap from Waters (Milford, MA) and a $15 \mathrm{~cm}$ long, $75 \mu \mathrm{m}$ inner diameter PicoFrit column from New Objective (Woburn, MA) packed in-house with Jupiter $\mathrm{C}_{18}$ particles from Phenomenex (Torrance, CA). The gradient program began with 3\% B ( $0.1 \%$ formic acid, $0.005 \%$ TFA in $90 \% \mathrm{AcN})$ for $5 \mathrm{~min}$ to wash the sample, followed by a gradient up to $30 \% \mathrm{~B}$ over $40 \mathrm{~min}$, to $50 \% \mathrm{~B}$ at $60 \mathrm{~min}$, to $70 \% \mathrm{~B}$ at $65 \mathrm{~min}$, and held at $90 \% \mathrm{~B}$ from 70 to $78 \mathrm{~min}$. The LC-ESI$\mathrm{Q}$-TOF mass spectrometer (Global Ultima; Micromass, 
Ltd., Manchester, UK) was used with a spray voltage of 3.5 $\mathrm{kV}$. The MS/MS data was recorded using a $0.5 \mathrm{sec}$ MS survey scan and $2.5 \mathrm{sec}$ MS/MS scans on the three most abundant ions found in the survey scan. The CID energy was between 25 and $65 \mathrm{eV}$ depending on the mass and charge state of the precursor ions.

\section{MALDI-TOFITOF MS}

The in-pot tryptic digest sample was loaded on a Symmetry $300 \mathrm{C}_{18}$ trap and a $150 \mathrm{~mm}$ by $0.32 \mathrm{~mm}$ Symmetry column both packed with $5 \mu \mathrm{m} \mathrm{C}_{18}$ particles from Waters for off-line HPLC separation before the mass analysis. The same gradient was used as in the LC-ESI-Q-TOF MS with solvent $\mathrm{A}\left(0.1 \%\right.$ TFA and $1 \% \mathrm{AcN}$ in $\left.\mathrm{H}_{2} \mathrm{O}\right)$ and solvent $\mathrm{B}$ $\left(0.1 \%\right.$ TFA and $1 \% \mathrm{H}_{2} \mathrm{O}$ in $\left.\mathrm{AcN}\right)$ with a flow rate of $3 \mu \mathrm{L} /$ min from a Waters CapLC system. The elutant from the column was automatically mixed with $1 \mu \mathrm{L} / \mathrm{min}$ of 0.6 $\mathrm{mg} / \mathrm{mL} \mathrm{HCCA}$ and $0.08 \mathrm{mg} / \mathrm{mL}$ ammonium phosphate in 50:50 AcN: $\mathrm{H}_{2} \mathrm{O}$ containing $0.1 \%$ TFA. The sample was passed through a $75 \mu \mathrm{m}$ capillary at a combined rate of 4 $\mu \mathrm{L} / \mathrm{min}$ into a Waters MALDIprep sprayer (Life Sciences $\mathrm{R}$ \& D Laboratory, Waters Corporation). A spotting time of 45 second per spot, a nitrogen flow rate of $7 \mathrm{psi}$, and a temperature gradient of $-2{ }^{\circ} \mathrm{C} / 7 \mathrm{~min}\left(65^{\circ} \mathrm{C}\right.$ to $45^{\circ} \mathrm{C}$ over $90 \mathrm{~min}$ ) was used. For MALDI tandem mass spectrometry an Applied Biosystems 4700 proteomics Analyzer (Applied Biosystem, Inc., Framingham, MA) was used. MS data were acquired using the reflector mode. Ten tandem mass spectra were recorded from each spot. Ions with a signal to noise $(\mathrm{S} / \mathrm{N})$ ration greater than 30 were chosen for tandem mass spectrometry. The tandem mass spectra were recorded by accelerating the precursor ions to $8 \mathrm{keV}$, selecting with the timed gate set to $3 \mathrm{Da}$, and performing the collision induced dissociation (CID) at $1 \mathrm{keV}$. The gas pressure (air) in the CID cell was at $6 \times 10^{-7}$ Torr and the fragment ions were accelerated to $14 \mathrm{keV}$ before entering the reflector.

\section{Data Analysis}

Mascot (Matrix Science, London, UK) software was used for the protein identification. The uninterpreted tandem mass spectral data were searched against a VV protein database created in-house based on the complete DNA sequence of vaccinia virus (PUBMED 2219722). Specifically, 273 protein sequences in FASTA format were organized and loaded onto the in-house Mascot primary sequence database. All MS data was also searched against the MSDB database, a composite, non-identical protein sequence database built from a number of primary source databases (Matrix Science). The LC-ESI-QIT MS data was converted into Sequest DTA files and searched with the Mascot program.

\section{Competing interests}

The author(s) declare that there are no competing interests.

\section{Authors' contributions}

JDY conceived of the study, participated in its design and coordination, assisted with sample preparation, and drafted the manuscript. CRG assisted with the propagation of virus, prepared the samples for analysis, and helped analyze the mass spectrometry data. TSC prepared samples for analysis, analyzed the mass spectrometry data and helped to draft the manuscript. SV assisted with the analysis of the mass spectrometry data. DEH and CSM coordinated the research efforts and edited the manuscript. All authors read and approved the final manuscript.

\section{Acknowledgements}

This work was supported by National Institutes of Health grants Al2335 and Al05933I. This publication was also made possible in part by grant $\mathrm{P} 30$ ESO02 I 0 from the National Institutes of Environmental Health Sciences, $\mathrm{NIH}$.

Special thanks to Gabriela Morin for her assistance with propagating and purifying the vaccinia virus for this project. We would also like to thank Elizabeth Barofsky and Brian Arbogast for their assistance with the MALDITOF/TOF MS, LC-ESI-Q-TOF MS, and LC-ESI-QIT MS.

\section{References}

I. Kortepeter MG, Parker GW: Potential biological weapons threats. Emerg Infect Dis 1999, 5:523-527.

2. Goebel SJ, Johnson GP, Perkus ME, Davis SW, Winslow JP, Paoletti E: The complete DNA sequence of vaccinia virus. Virol 1990, I 79:247-266.

3. Moss B: Poxviridae: The Viruses and Their Replication. In Fields Virology Volume Volume 2. 3rd Edition edition. Edited by: Fields BN. Philadelphia , Lippincott-Raven; 1996:2637-267I.

4. Johnson GP, Goebel SJ, Paoletti E: An update on the vaccinia virus genome. Virol 1993, 196:381-401.

5. Jensen O, Houthaeve T, Shevchenko A, Cudmore S, Ashford T, Mann $M$, Griffiths G, Locker J: Identification of the major membrane and core proteins of vaccinia virus by two-dimensional electrophoresis. Journal of Virology 1996, 70( I I):7485-7497.

6. Murcia-Nicolas A, Bolbach G, Blais JC, Beaud G: Identification by mass spectroscopy of three major early proteins associated with virosomes in vaccinia virus-infected cells. Virus Res 1999 , 59(I): I-I2.

7. Stapels MD, Barofsky DF: Complementary use of MALDI and ESI for the HPLC-MS/MS Analysis of DNA-binding proteins. Anal Chem 2004, 76:5423-5430.

8. Dainese Hatt P, Quadroni M, Staudenmann W, James P: Concentration of, and SDS removal from proteins isolated from multiple two-dimensional electrophoresis gels. Eur J Biochem 1997 246(2):336-343.

9. Altschul SF, Madden TL, Schaffer AA, Zhang J, Zhang Z, Miller W, Lipman DJ: Gapped BLAST and PSI-BLAST: a new generation of protein database search programs. Nucleic Acids Res 1997, 25:3389-3402.

10. Kyte J, Doolittle RF: A simple method for displayng the hydropathic character of a protein. J Mol Biol 1982, I57(I): I05-I32.

II. Yoder JD, Chen TS, Hruby DE: Sequence independent acylation of the vaccinia virus A-type inclusion protein. Biochem 2004, 43(26):8297-8302

12. Zachertowska A, Brewer D, Evans DH: Characterization of the major capsid proteins of myxoma virus particles using MALDI-TOF mass spectrometry. J Virol Methods in press. 
13. Hruby DE, Guarino LA, Kates JR: Vaccinia virus replication. I. Requirement for host-cell nucleus. J Virol 1979, 29:705-7I5.

14. Spencer E, Shuman S, Hurwitz J: Purification and properties of vaccinia virus DNA-dependent RNA polymerase. I Biol Chem 1980, 255:5388-5395.

15. Laemmli UK: Cleavage of structural proteins during the assembly of the head of bacteriophage T4. Nature 1970, 227(259):680-685.

16. Shevchenko A, Wilm M, Vorm O, Mann M: Mass spectrometric sequencing of proteins silver-stained polyacrylamide gels. Anal Chem 1996, 68(5):850-858

17. Rosel J, Moss B: Transcriptional and translational mapping and nucleotide sequence analysis of a vaccinia virus gene encoding the precursor of the major core polypeptide $4 \mathrm{~b}$. J Virol 1985, 56(3):830-838.

18. Demkowicz WE, Maa JS, Esteban M: Identification and characterization of vaccinia virus genes encoding proteins that are highly antigenic in animals and are immunodominant in vaccinated humans. J Virol 1992, 66(I):386-398.

19. Ahn BY, Rosel J, Cole NB, Moss B: Identification and expression of rpol9, a vaccinia virus gene encoding a l9-kilodalton DNA-dependent RNA polymerase subunit. J Virol 1992, 66(2):97|-982.

20. Gershon PD, Moss B: Early transcription factor subunits are encoded by vaccinia virus late genes. Proc Natl Aca Sci 1990 87( I I):440I-4405.

21. Van Meir E, Wittek R: Fine structure of the vaccinia virus gene encoding the precursor of the major core protein $4 \mathrm{a}$. Arch Virol 1988, 102(I-2): 19-27.

22. Whitehead SS, Hruby DE: Differential utilization of a conserved motif for the proteolytic maturation of vaccinia virus proteins. Virol 1994, 200(I):|54-16|.

23. Salmons T, Kuhn A, Wylie F, Schleich S, Rodriguez JR, Rodriguez D, Esteban M, Griffiths G, Locker JK: Vaccinia virus membrane proteins $p 8$ and p 16 are cotranslationally inserted into the rough endoplasmic reticulum and retained in the intermediate compartment. J Virol I997, 7I( I 0):7404-7420.

24. Szajner $P$, Jaffe $H$, Weisberg AS, Moss B: A complex of seven vaccinia virus proteins conserved in all chordopoxviruses is required for the association of membranes and viroplasm to form immature virions. Virol 2004, 330(2):447-459.

25. Martin KH, Grosenbach DW, Franke CA, Hruby DE: Identification and analysis of three myristylated vaccinia virus late proteins. J Virol 1997, 7I(7):5218-5226

26. Ojeda S, Senkevich TG, Moss B: Entry of Vaccinia virus and cellcell fusion require a highly conserved cysteine-rich membrane protein encoded by the AI6L gene. J Virol 2006, 80(I):5I-6I.

27. Rodriguez D, Rodriguez JR, Esteban M: The vaccinia virus I 4-kilodalton fusion protein forms a stable complex with the processed protein encoded by the vaccinia virus A I 7 gene. J Virol 1993, 67(6):3435-3440.

28. Rodriguez D, Esteban M, Rodriguez JR: Vaccinia virus AI7L gene product is essential for an early step in virion morphogenesis. J Virol 1995, 69(8):4640-4648.

29. Patel DD, Pickup DJ: The second-largest subunit of the poxvirus RNA polymerase is similar to the corresponding subunits of procaryotic and eucaryotic RNA polymerases. I Virol 1989, 63(3): $1076-1086$

30. Rodriguez $D$, Esteban M: Mapping and nucleotide sequence of the vaccinia virus gene that encodes a |4-kilodalton fusion protein. J Virol I 987, 6 I (I I):3550-3554

31. Amegadzie BY, Ahn BY, Moss B: Identification, sequence, and expression of the gene encoding a Mr 35,000 subunit of the vaccinia virus DNA-dependent RNA polymerase. J Biol Chem 1991, 266(2I):13712-13718.

32. Szajner $P$, Weisberg AS, Wolffe EJ, Moss B: Vaccinia virus A30L protein is required for association of viral membranes with dense viroplasm to form immature virions. J Virol 200I, 75(13):5752-576I.

33. Roper RL, Payne LG, Moss B: Extracellular vaccinia virus envelope glycoprotein encoded by the A33R gene. J Virol 1996, 70(6):3753-3762.

34. Duncan SA, Smith GL: Identification and characterization of an extracellular envelope glycoprotein affecting vaccinia virus egress. J Virol 1996, 66(3): 1610-1621.
35. Blasco R, Cole NB, Moss B: Sequence analysis, expression, and deletion of a vaccinia virus gene encoding a homolog of profilin, a eukaryotic actin-binding protein. J Virol 1991, 65(9):4598-4608.

36. Bowie A, Kiss-Toth E, Symons JA, Smith GL, Dower SK, O'Neill LA: $A 46 R$ and A52R from vaccinia virus are antagonists of host IL-I and toll-like receptor signaling. Proc Natl Aca Sci 2000, 97(18): 10162-10167.

37. Shida $\mathrm{H}$ : Nucleotide sequence of the vaccinia virus hemagglutinin gene. Virol 1986, I50(2):45I-462.

38. Engelstad M, Howard ST, Smith GL: A constitutively expressed vaccinia gene encodes a 42-kDa glycoprotein related to complement control factors that forms part of the extracellular virus envelope. Virol I992, I 88(2):80I-8IO.

39. Kettle S, Blake NW, Law KM, Smith GL: Vaccinia virus serpins BI3R (SPI-2) and B22R (SPI-I) encode M(r) 38.5 and 40K, intracellular polypeptides that do not affect virus virulence in a murine intranasal model. Virol 1995, 206(I): I36-147.

40. Morgan JR, Cohen LK, Roberts BE: Identification of the DNA sequences encoding the large subunit of the mRNA-capping enzyme of vaccinia virus. J Virol I984, 52(I):206-2I4

41. Dyster LM, Niles EG: Genetic and biochemical characterization of vaccinia virus genes $D 2 L$ and $D 3 R$ which encode virion structural proteins. Virol I99I, 182(2):455-467.

42. Broyles SS, Fesler BS: Vaccinia virus gene encoding a component of the viral early transcription factor. J Virol 1990 64(4): $1523-1529$

43. Niles EG, Seto J: Vaccinia virus gene D8 encodes a virion transmembrane protein. J Virol I988, 62(10):3772-3778.

44. Chernos VI, Vovk TS, Ivanova ON, Antonova TP, Loparev VN: [Insertion mutants of the vaccinia virus. The effect of inactivating E7R and D8L genes on the biological properties of the virus]. Mol Gen Mikrobiol Virusol 1993, Mar-Apr(2):30-34.

45. Broyles SS, Moss B: Identification of the vaccinia virus gene encoding nucleoside triphosphate phosphohydrolase I, a DNA-dependent ATPase. J Virol 1987, 6 I(5): I738-1742.

46. Niles EG, Lee-Chen G], Shuman S, Moss B, Broyles SS: Vaccinia virus gene DI2L encodes the small subunit of the viral mRNA capping enzyme. Virol 1989, I72(2):5।3-522.

47. Brakel C, Kates JR: Poly(A) polymerase from vaccinia virusinfected cells. I. Partial purification and characterization. J Virol 1974, I4(4):715-723.

48. Gershon PD, Ahn BY, Garfield M, Moss B: Poly(A) polymerase and a dissociable polyadenylation stimulatory factor encoded by vaccinia virus. Cell 1991, 66(6):1269-1278.

49. Chang HW, Watson JC, Jacobs BT: The E3L gene of vaccinia virus encodes an inhibitor of the interferon-induced doublestranded RNA-dependent protein kinase. Proc Natl Aca Sci 1992, 89:4825-4829.

50. Ahn BY, Gershon PD, Jones EV, Moss B: Identification of rpo30, a vaccinia virus RNA polymerase gene with structural similarity to a eucaryotic transcription elongation factor. Mol Cell Biol 1990, I O( I 0):5433-544I.

5I. Tolonen N, Doglio L, Schleich S, Krijnse Locker J: Vaccinia virus DNA replication occurs in endoplasmic reticulum-enclosed cytoplasmic mini-nuclei. Mol Bio Cell 200I, I 2(7):203I-2046.

52. Doglio L, De Marco A, Schleich S, Roos N, Krijnse Locker J: The Vaccinia virus E8R gene product: a viral membrane protein that is made early in infection and packaged into the virions' core. J Virol 2002, 76(19):9773-9786.

53. Senkevich TG, White CL, Koonin EV, Moss B: A viral member of the ERVI/ALR protein family participates in a cytoplasmic pathway of disulfide bond formation. Proc Natl Aca Sci 2000, 97(22): 12068-12073

54. Wang SP, Shuman S: A temperature-sensitive mutation of the vaccinia virus EII gene encoding a $15-\mathrm{kDa}$ virion component. Virol 1996, 2 I 6(I):252-257.

55. Higley S, Way M: Characterization of the vaccinia virus F8L protein. J Gen Virol 1997, 78( (10):2633-2637.

56. Kleiman $\mathrm{JH}$, Moss B: Characterization of a protein kinase and two phosphate acceptor proteins from vaccinia virions. J Biol Chem 1975, 250(7):2430-2437.

57. Lin S, Broyles SS: Vaccinia protein kinase 2: a second essential serine/threonine protein kinase encoded by vaccinia virus. Proc Natl Aca Sci 1994, 9 I ( I6):7653-7657. 
58. Blasco R, Moss B: Extracellular vaccinia virus formation and cell-to-cell virus transmission are prevented by deletion of the gene encoding the 37,000-Dalton outer envelope protein. J Virol I99I, 65(I I):5910-5920.

59. Kao SY, Ressner E, Kates J, Bauer WR: Purification and characterization of a superhelix binding protein from vaccinia virus. Virol I98I, I I I(2):500-508.

60. Whitehead SS, Hruby DE: A transcriptionally controlled transprocessing assay: putative identification of a vaccinia virusencoded proteinase which cleaves precursor protein P25K. J Virol 1994, 68(I I):7603-7608

6I. Senkevich TG, Ojeda S, Townsley A, Nelson GE, Moss B: Poxvirus multiprotein entry-fusion complex. Proc Natl Aca Sci 2005, I02(5 I): 18572- I8577.

62. Gvakharia BO, Koonin EK, Mathews CK: Vaccinia virus G4L gene encodes a second glutaredoxin. Virol 1996, 226(2):408-4II

63. Szajner $P$, Jaffe $H$, Weisberg AS, Moss B: Vaccinia virus G7L protein Interacts with the A30L protein and is required for association of viral membranes with dense viroplasm to form immature virions. J Virol 2003, 77(6):34| 8-3429.

64. Guan KL, Broyles SS, Dixon JE: A Tyr/Ser protein phosphatase encoded by vaccinia virus. Nature I991, 350(63 I6):359-362.

65. Zinov'ev VV, Ovechkina LG, Matskova LV, Balakhnin SM, Malygin EG, Chertov OI, Telezhinskaia IN, Zaitseva EV, Golubeva TB: [Identification of the gene for the immunodominant $\mathrm{p} 35$ protein from vaccinia virus]. Mol Biol (Mosk) I992, 26(I): | 42-I49.

66. Ahn BY, Moss B: RNA polymerase-associated transcription specificity factor encoded by vaccinia virus. Proc Natl Aca Sci 1992, 89(8):3536-3540.

67. Gordon J, Kovala T, Dales S: Molecular characterization of a prominent antigen of the vaccinia virus envelope. Virol 1988 , 167(2):361-369.

68. Klemperer N, Ward J, Evans E, Traktman P: The vaccinia virus II protein is essential for the assembly of mature virions. J Virol 1997, 7 I ( I 2):9285-9294.

69. Polisky B, Kates J: Vaccinia virus intracellular DNA-protein complex: biochemical characteristics of associated protein. Virol 1972, 49(1): 168-179.

70. Rochester SC, Traktman P: Characterization of the singlestranded DNA binding protein encoded by the vaccinia virus 13 gene. J Virol 1998, 72(4):2917-2926.

7I. Netesova NA, Muravlev Al, Chikaev NA, Malygin EG: [A structureactivity study of the HindIII-I fragment of the L-IVP strain of vaccinia virus genome. I. Cloning of 15 gene and identification of its protein product]. Mol Biol (Mosk) 1995, 25(6): $1526-1532$.

72. Byrd CM, Bolken TC, Hruby DE: The vaccinia virus I7L gene product is the core protein proteinase. I Virol 2002, 76(I7):8973-8976.

73. Koonin EV, Senkevich TG: Vaccinia virus encodes four putative DNA and/or RNA helicases distantly related to each other. J Gen Virol 1992, 73(4):989-993.

74. Ciu WL, Chang W: Vaccinia virus JIR protein: a viral membrane protein that is essential for virion morphogenesis. Virol 2002, 76(1 9):9575-9587.

75. Schnierle BS, Gershon PD, Moss B: Cap-specific mRNA (nucleoside-O2-)-methyltransferase and poly(A) polymerase stimulatory activities of vaccinia virus are mediated by a single protein. Proc Natl Aca Sci 1992, I 8 I(7):727-732.

76. Broyles SS, Moss B: Homology between RNA polymerases of poxviruses, prokaryotes, and eukaryotes: nucleotide sequence and transcriptional analysis of vaccinia virus genes encoding $147-\mathrm{kDa}$ and 22-kDa subunits. Proc Natl Aca Sci 1986 , 83(I0):3|4|-3|45.

77. Cao JX, Koop BF, Upton C: A human homolog of the vaccinia virus HindIII K4L gene is a member of the phospholipase $D$ superfamily. Vir Res 1997, 48(I): II-I8.

78. Franke CA, Wilson EM, Hruby DE: Use of a cell-free system to identify the vaccinia virus $L I R$ gene product as the major late myristylated virion protein M25. J Virol I990, 64(I 2):5988-5996.

79. WP Y, WR B: Purification and characterization of vaccinia virus structural protein VP8. Virol 1988, 167(2):578-584.

80. Johnson GP, Goebel SJ, Perkus ME, Davis SW, Winslow JP, Paoletti E: Vaccinia virus encodes a protein with similarity to glutaredoxins. Virol I99I, I8I(1):378-38I.
81. Ahn BY, Moss B: Glutaredoxin homolog encoded by vaccinia virus is a virion-associated enzyme with thioltransferase and dehydroascorbate reductase activities. Proc Natl Aca Sci 1992, 89(I5):7060-7064.
Publish with Biomed Central and every scientist can read your work free of charge

"BioMed Central will be the most significant development for disseminating the results of biomedical research in our lifetime. "

Sir Paul Nurse, Cancer Research UK

Your research papers will be:

- available free of charge to the entire biomedical community

- peer reviewed and published immediately upon acceptance

- cited in PubMed and archived on PubMed Central

- yours - you keep the copyright 